\title{
Battelle
}

Human Affairs Research Centers 4000 N.E. 41st Street/Seattle, Washington 98105

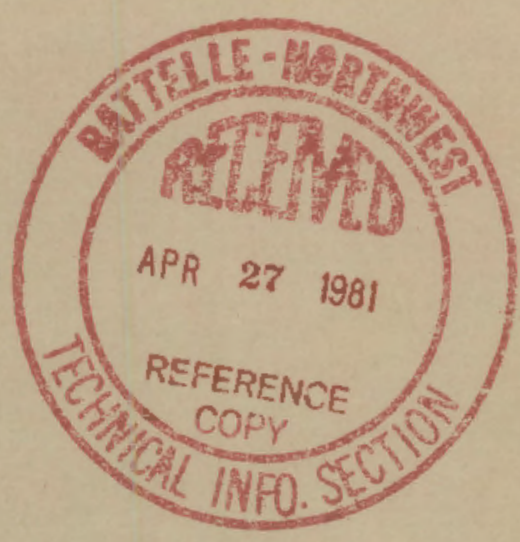

\section{A COMPARATIVE ANALYSIS OF PRINT MEDIA COVERAGE OF NUCLEAR POWER AND COAL ISSUES}

\author{
Stanley M. Nealey \\ William L. Rankin \\ Daniel E. Montano
}

October, 1978

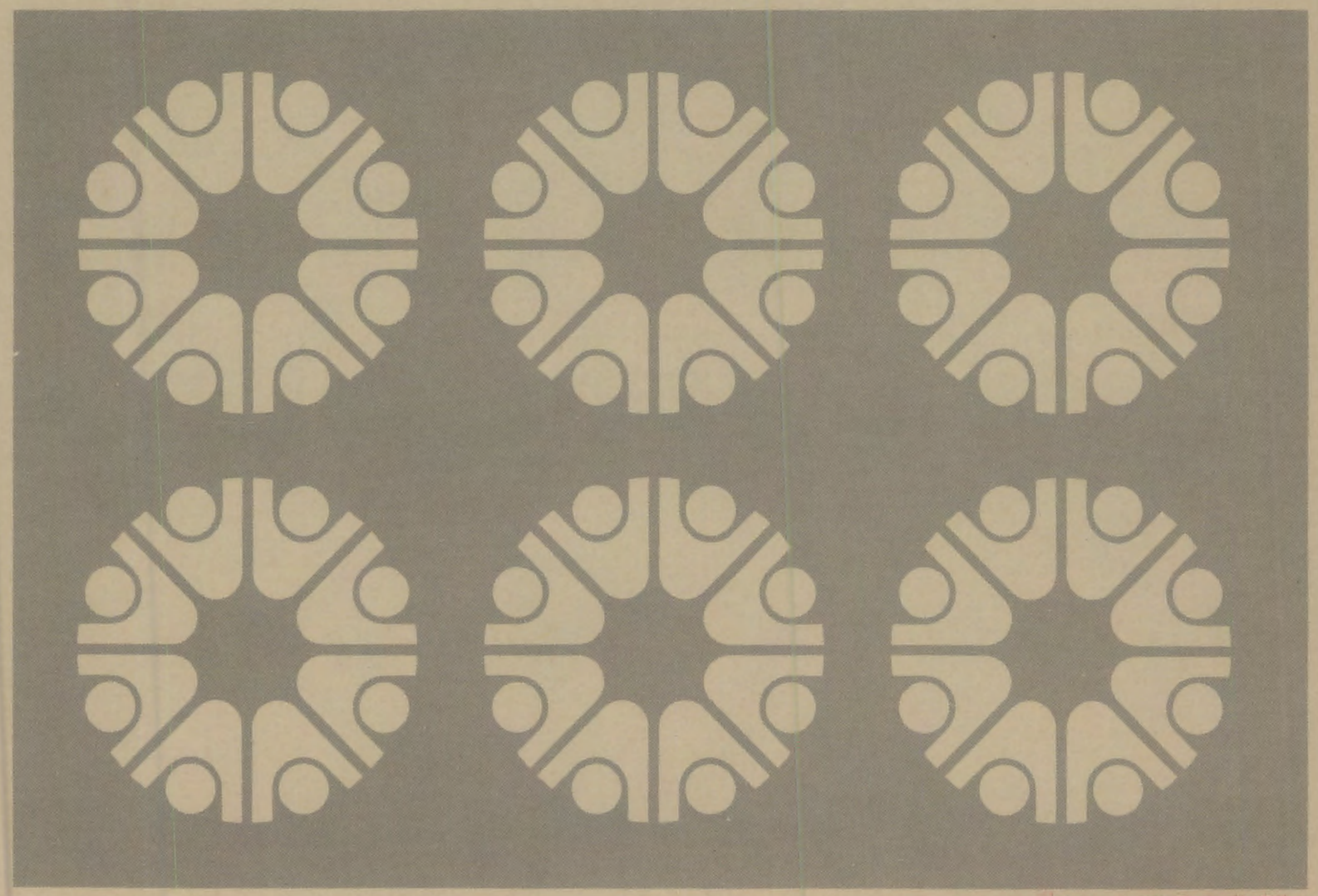

MEFEDESE PRPY 


\section{NOTICE}

This report was prepared as an account of work sponsored by the United States Government. Neither the United States nor the Department of Energy, nor any of their employees, nor any of their contractors, sub-contractors, or their employees, makes any warranty, express or implied, or assumes any legal liability or responsibility for the accuracy. completeness or usefulness of any information, apparatus, product or process disclosed, or represents that its use would not infringe privately owned rights.

The views, opinions and conclusions contained in this report are those of the contractor and do not necessarily represent those of the United States Government or the United States Department of Energy. 
A COMPARATIVE ANALYSIS OF PRINT MEDIA COVERAGE

OF NUCLEAR POWER AND COAL ISSUES

Topical Report

Stanley M. Nealey

William L. Rankin

Daniel E. Montano

Prepared for the Waste Management Systems Studies Program of the Pacific Northwest Laboratory of the U.S. Department of Energy under contract EW-78-C-06-1076

Battelle Memorial Institute Human Affairs Research Centers Social Change Study Center Energy and Environment Program Seattle, Washington 98105 


\section{TABLE OF CONTENTS}

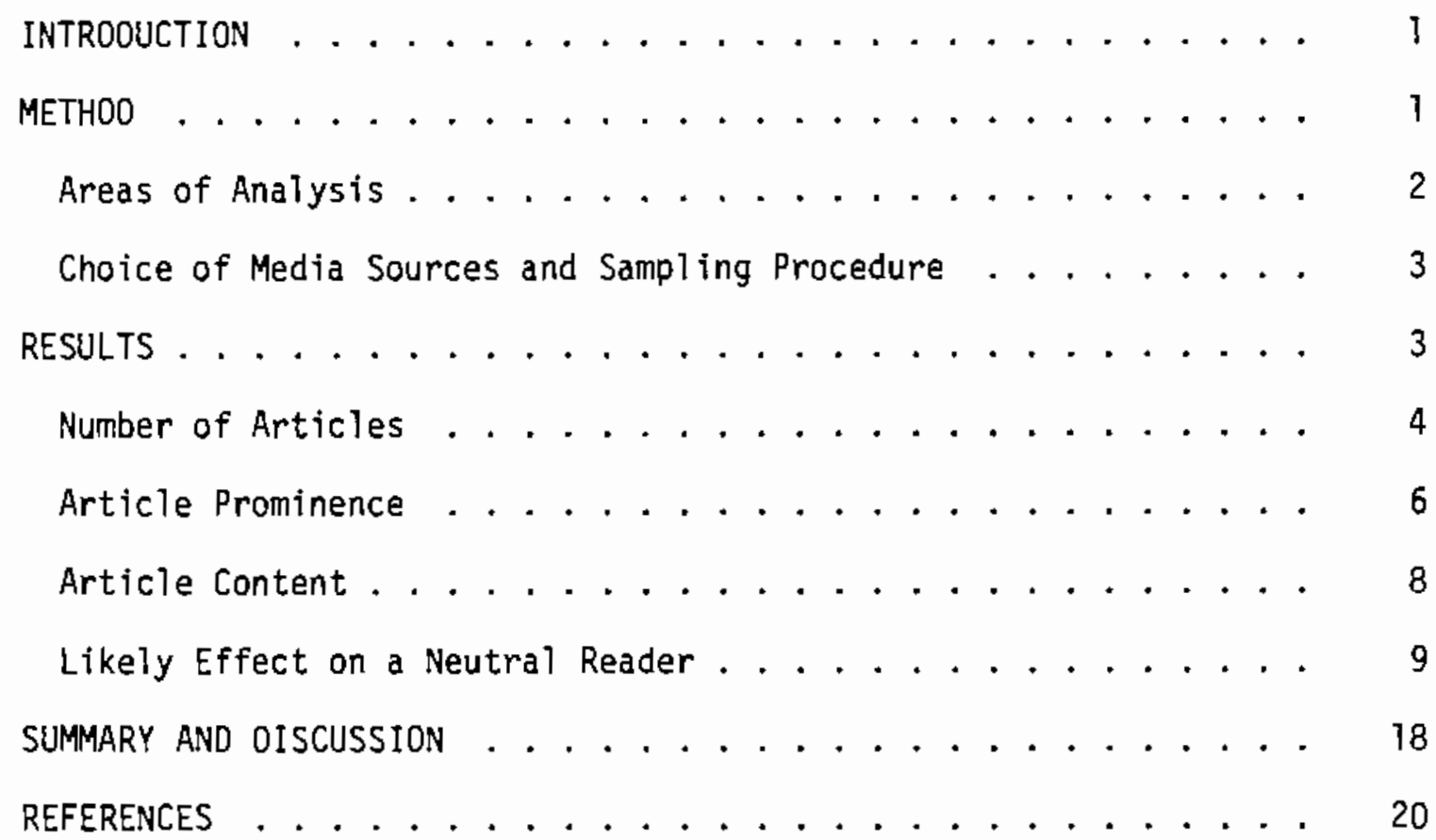




\section{LIST OF TABLES}

1. Differences in Article Characteristics of Nuclear

Power and Coal Articles as a Function of Media Type ..... 7

2. Differences in the Likely Effect of Newspaper Articies

on a Neutral Reader as a Function of Source........ 11

3. Differences in the Likeiy Effect of Magazine Articles

on a Neutral Reader as a Function of Source ........ 12

4. Differences in the Discussion of Benefits and Costs

of Nuclear Power and Coal as a Function of

Newspaper Sources ................ 15

5. Differences in the Discussion of Benefits and Costs

of Nuclear Power and Coal as a Function

of Magazine Source . . . . . . . . . . . . . 


\section{LIST OF FIGURES}

1. Number of Nuclear Power and Coal Articles by Year . . . . . . 5

2. The Number of Pro, Neutral, and Anti Nuclear Power and

Coal Articles by Year . . . . . . . . . . . . . 14 


\section{INTRODUCTION}

The purpose of this report is to provide information on the treatment given energy topics by selected newspapers and magazines. Rankin, Nealey, and Montano (1978) reported print media handling of one energy technology, nuclear power, in an earlier report. Although the nuciear power findings were informative regarding article prominence, article content, and the likely effect that the article would have on a neutral reader, the lack of information regarding print media handling of other energy technologies precluded a comparative assessment. As often happens with controversial issues, both opponents and proponents of continued nuclear development feel the media present a biased picture. Since coal is prominently featured in national energy plans and is often mentioned as an alternative to nuclear power development, it seemed useful to analyze print media handling of coal using the same methods we used in the earlier study to analyze print media handling of nuclear power. This report is thus a follow-on study to the Rankin et al. (1978) study. It allows a comparative assessment of print media handling of both coal and nuclear power. A portion of the data from Rankin et al. (1978) will be repeated in this report.

\section{METHOD}

The methods of analysis are reported in full in Rankin et al. (1978), so that only a brief summary will be presented here. Identical content analysis procedures were used to analyze print media stories about both nuclear power and coal. Content analysis allows collection of quantifiable data using raters with known measurement reliability and has been used successfully 
by other print media anaiysis. Articles were analyzed for prominence, content, and the likeiy effect they would have on a neutral reader.

Areas of Analysis

Article prominence. Article prominence was measured in four ways. First, the type of article was recorded (wire story, local news story, editoria1, or feature article). Second, we recorded whether newspaper articles were on the front page, first page of a section other than the first section, or other; magazine articles were rated as a cover story or other. Third, the length of the articles was measured. Fourth, each article was rated as to whether it was written in response to a specific event (event oriented) or not (issue oriented).

Article content. The content of each article was rated on two content lists: (1) areas of the fuel cycle discussed, and (2) specified issues discussed. The content categories on both lists were determined after reviewing a sample of articles. The most prominent fuel cycle areas and specific issues were coded with a "2," other areas and issues mentioned were coded $" 1, "$ and areas and issues not mentioned were coded "0."

Likely effect of article on a neutral reader. Since the media are of ten perceived as influential in swaying readers one way or another on controversial issues, we sought to determine what effect a given article might have on a hypothetical neutral reader. By a "neutral reader" we simply mean someone who is undecided about the merits of a given energy technology. Two ratings were made. First, we judged the degree to which each article discussed the benefits and/or costs of the energy technology. Second, we made a judgment as to whether each article seemed to promote the technology, to oppose the technology, or to remain neutral about the technology. 
Choice of Print Media Sources and

Sampling Procedure

Because we wished to carry out a comparative analysis, our choice of sources was determined by the earlier Rankin et al. (1978) study. Three newspapers were content analyzed--the New York Times, the Seattle Post-Intell igencer, and the National Observer. The Chicago Tribune, which was included in the earifier study, was not used in this study because 60 percent of the Chicago Tribune articles for our period of analysis were not availabie to us. As in the previous study, four magazines were content analyzed--Time, Business Week, Scientific American, and Environment.

Our analys is was carried out for all seven sources for the five-year period from 1972 through 1976. All issues of the four magazines were content analyzed. All issues of the weekly National Observer were also content analyzed. However, the New York Times and the Seattle Post-Intelligencer were only content analyzed for four one-week periods per year (one each calendar quarter), as was done in the previous study. These weeks were the same as in the earlier study to allow a direct comparison of news handling of the two energy technologies during the same period.

\section{RESULTS}

Since the purpose of this study is to provide a comparative analysis of nuclear and coal stories, the results to be presented will include some data from the earlier nuclear power study by Rankin et al. (1978) as well as the coal data compiled just for this analysis. The nuclear power data we report here differ, at times, from those reported in Rankin et al. (197B). This is because the Chicago Tribune nuclear power articles are not included in the present comparative analysis. 
Number of Articles

One measure of importance is the number of articles printed on nuclear power and coal. Using this criterion, the print media sources we analyzed found nuclear power to be much more important than coal. Our sampling procedure uncovered 206 nuclear power newspaper articles compared to only 124 coal articles. With regard to magazines, we found 124 nuclear power articles compared to only 67 coal articles. Using this as a criterion, the print media treated nuclear power as about twice as newsworthy as coal.

This difference held across all news sources, except Time magazine. The number of nuclear power and coal articles for the seven media sources were, respectively: New York Times, 131 and 89; Seattle Post-Intelligencer, 41 and 20; National Observer, 34 and 15; Time, 14 and 14; Business Week, 44 and 38; Scientific American, 18 and 8; Environment, 48 and 7. Thus, Environment, especialiy, found nuclear power to be much more newsworthy than coal.

The comparison of the number of nuclear and coal articles as a function of time shows different patterns of media coverage for the two technologies (see Figure 1). Whereas nuclear power articles continued, somewhat steadily, to increase in number from 1972 through 1976, such was not the case for coal articles. The number of coal articles, both for newspapers and for magazines, peaked in 1974 following the Arab oil embargo of 1973-1974 and decreased in 1975 and 1976. Thus, nuclear power issues have gained in media importance since 1972 while coverage of coal issues seems more dependent on specific events, such as the oil embargo. The peak in coverage of both technologies in 1974 fell off in subsequent years for coal, but coverage of nuclear power increased again in 1976. 


\section{FIGURE 1}

Number of Nuclear Power and Coal Articles by Year

Number of Articles

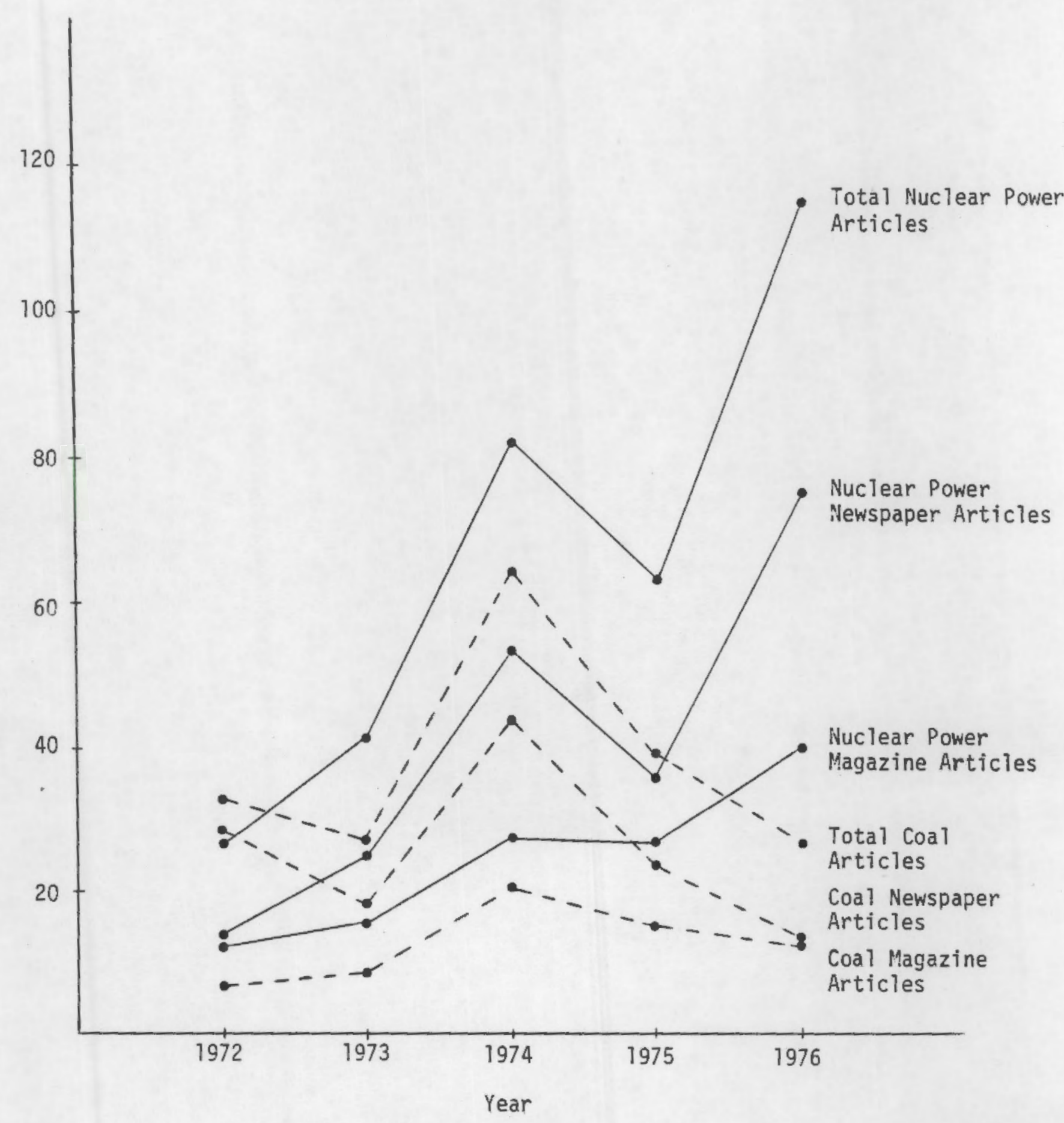




\section{Article Prominence}

There were a few significant differences in the prominence accorded to nuclear power and coal articles (see Table 1). A two-way analysis of variance was used to compare the distribution of articles among the prominence categories for nuclear power and coal. There was a significant difference between newspaper nuclear power and coal stories regarding story type $(\mathrm{p}<.001)$. This difference is mainly attributable to the facts that relatively more coal articles were wire stories, and relatively fewer coal articles were editorials. Assuming that wire stories are less indicative of article prominence than editorials, this finding indicates that newspapers accorded more prominence to nuclear power than to coal.

The location of newspaper nuclear power and coal stories also differed significantly $(\mathrm{p}<.05)$. This difference was largely due to the fact that relatively more nuclear power than coal stories were found on the first page of a newspaper section other than the first section. Thus, slightly more prominence, in terms of location, was accorded to newspaper nuclear power stories than to coal stories.

The final two significant differences with regard to newspaper and magazine coverage both deal with article orientation $(\mathrm{p}<.001)$. Whereas 94.2 percent of the newspaper and 99.2 percent of the magazine nuclear power articles were predominantly issue-oriented, only 58.1 percent of the newspaper and 86.6 percent of the magazine coal articles were issue-oriented. It would appear that the salience of nuclear power as a social issue would cause nuclear events, when they occur, to be newsworthy. Since few nuclear articles report new events, it seems likely that relatively few nuclear events actually occur. However, since the volume of nuclear stories is quite high, 
TABLE 1

Differences in Article Characteristics

of Nuclear Power and Coal Articles

as a Function of Media Type

\begin{tabular}{|c|c|c|c|c|c|c|}
\hline \multirow[b]{2}{*}{ Characteristics } & \multicolumn{3}{|c|}{ Newspapers } & \multicolumn{3}{|c|}{ Mgazines } \\
\hline & $\begin{array}{l}\text { Nuclear } \\
\text { Power }\end{array}$ & Coal & $\mathbf{e}^{\mathbf{a}}$ & $\begin{array}{l}\text { Muclear } \\
\text { Power }\end{array}$ & $\cos 1$ & R \\
\hline \multicolumn{7}{|l|}{ Story Type } \\
\hline \multirow[t]{2}{*}{$\begin{array}{l}\text { Wire story } \\
\text { Local news story/news article } \\
\text { Editorial } \\
\text { Feature article }\end{array}$} & $\begin{array}{l}68(33.0 \%) \\
79(38.3 \%) \\
31(15.0 \%) \\
28(13.6 \%) \\
\end{array}$ & $\begin{array}{r}66(53.2 \%) \\
28(22.6 \%) \\
B(6.5 \%) \\
22(17.7 \%) \\
\end{array}$ & .001 & $\begin{array}{l}60 \\
12 \\
52 \\
52 \\
\end{array}$ & $\begin{array}{r}41(61.2 x) \\
51\left(\begin{array}{r}7.5 \% \\
31.3 x\end{array}\right) \\
\end{array}$ & n.s. \\
\hline & 206 & 124 & & 124 & 67 & \\
\hline \multicolumn{7}{|l|}{ Location } \\
\hline \multirow{3}{*}{$\begin{array}{l}\text { Front page of newspaper } \\
\text { First page of newspaper section } \\
\text { Cover story } \\
\text { Other }\end{array}$} & $\begin{array}{l}17(8.3 \%) \\
16(7.8 \%)\end{array}$ & 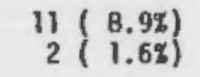 & & & & \\
\hline & $173(84.08)$ & $111(89.5 \%)$ & .05 & $\begin{array}{r}10(8.1 \%) \\
114(91.98) \\
\end{array}$ & $\begin{array}{r}2\left(\begin{array}{r}3.0 \%) \\
65\end{array}(97.0 \%)\right. \\
\end{array}$ & n.s. \\
\hline & 206 & 124 & & 124 & 67 & \\
\hline \multicolumn{7}{|l|}{ Length } \\
\hline \multirow[t]{2}{*}{$\begin{array}{l}\text { Less than } 1 / 2 \text { column } \\
\text { From } 1 / 2 \text { to } 2 \text { columns } \\
\text { Greater than } 2 \text { columns } \\
\text { Less than } 1 \text { page } \\
\text { From } 1 \text { to } 2 \text { pages } \\
\text { From } 2 \text { to } 5 \text { pages } \\
\text { Greater than } 5 \text { pages }\end{array}$} & $\begin{array}{l}99(48.1 \%) \\
88(42.7 \%) \\
19(9.2 \%)\end{array}$ & $\begin{array}{l}58(46.8 \%) \\
46(37.1 \%) \\
20(16.1 x)\end{array}$ & n.s. & $\begin{array}{r}62(50.0 \%) \\
35(28.2 \%) \\
9(7.3 \%) \\
18(14.5 \%) \\
\end{array}$ & $\begin{array}{r}36(53.7 \%) \\
19(28.4 \%) \\
3(4.5 \%) \\
9(13.4 \%) \\
\end{array}$ & n.s. \\
\hline & 206 & 124 & & 124 & 67 & \\
\hline \multicolumn{7}{|l|}{ Orientation } \\
\hline \multirow[t]{2}{*}{$\begin{array}{l}\text { Event-oriented } \\
\text { Issue-oriented }\end{array}$} & $\begin{array}{r}12(5.88) \\
194(94.28) \\
\end{array}$ & $\begin{array}{r}52(41.9 \%) \\
72(58.1 \%) \\
\end{array}$ & .001 & 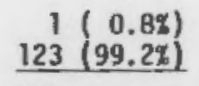 & $\begin{array}{r}9(13.4 \%) \\
58(86.6 \%) \\
\end{array}$ & .001 \\
\hline & 206 & 124 & & 124 & 67 & \\
\hline
\end{tabular}

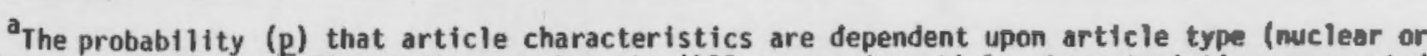
coal). A p of .05 or smaller indicates that the differences in article characteristics were not due simply to change but were due to a difference in media handling. Also, "n.5." is short for "not significant". 
it follows that issues dominate nuclear power coverage while events play a larger role in coal articles.

These data suggest that nuclear power was given more prominence than coal as a newsworthy topic by the print media, especially newspapers. Almost twice as many nuclear articles, compared to coal articles, were printed during our period of analysis. With regard to newspapers, the percentage of nuclear editorials was greater than the percentage of coal editorials, and nuclear articles were a bit more prominently located.

\section{Article Content}

Since the areas of the coal and nuclear fuel cycle differ, and since some of the nuclear power issues are not applicable to coal (e.g., reactor safety) and vice versa (e.g., strip mining), a direct comparison of nuclear power and coal areas and issues is not possible. However, the following generalizations can be made.

The major area of concern regarding coal stories was mining--57 articles (29.8\%) were mainly about coal mining. This was followed closely by articles on labor force concerns (49 articles or 25.7\%) and articles on laws or other controls affecting the use of coal (45 articles or 23.6\%) and more distantly by general coal articles (22 articles or 11.5\%). Coal gasification (5.2\%), power plant operation $(2.1 \%)$, and transportation (1.6\%) received much less print media attention. Thus mining, labor force concerns (largely strikes), and coal use regulation were the main areas of coal article concerns.

Rankin et al. (1978) found the emphasis on nuclear stories was much different. By far the biggest area of concern regarding nuclear power was reactor operation (147 articles or 44.5\%). This was followed distantly by international sharing of American nuclear technology (13.3\%), the breeder reactor 
$(9.7 \%)$, and general nuclear power articles $(6.7 \%)$. Only 2.7 percent of the nuclear articles were on mining, none were on labor force concerns, and 3.9 percent were on regulations affecting nuclear power. Thus, by far the most important nuclear area was reactor operation, whereas coal plant operation was not an important area for coal articies. None of the three major areas that were discussed in the coal articles were very important in the nuclear articles.

The main issues discussed in nuclear power and coal articles also differed. The most discussed coal issue was the need for political decisions regarding coal use $(20.9 \%)$ followed by strike issues $(8.9 \%$ on effects due to strike, $6.8 \%$ on strike negotiations, and $4.2 \%$ on employee wages for a total of $19.9 \%$ of the articles), health and safety issues (13.1\%), restoration of strip-mined land $(10.5 \%)$, technical problems regarding coal use $(9.9 \%)$, and the economics of coal (7.9\%).

However, the biggest nuclear power issue dealt with the economics of nuclear power (22.4\%), followed by health and safety issues (20.7\%) and political decisions regarding nuclear power (16.6\%) and, more distantly, by proliferation issues (7.8\%) and technical problems regarding nuclear power (5.2\%).

Thus, political issues in health and safety issues were both frequently the main issue area in nuclear power and coal articles. However, coal articles were often concerned with strikes, while nuclear articles were not; nuclear power articles were often concerned with economics, while coal articles were not.

\section{Likely Effect on a Neutral Reader}

Two procedures were used to estimate the likely effect that an article might have on a neutral reader. One measure was a judgment as to whether the 
article seemed to favor, to oppose, or to be neutral about the energy technology. The second measure was a judgment about the extent to which the articles discussed the benefits of the energy technology or the costs and risks of the energy technology.

Since Rankin et a1. (1978) reported that the results of the analyses of these two measures differed greatly across media sources, our analysis will focus both on individual sources and aggregate data. Table 2 shows the data for newspapers. The New York Times and the Seattle Post-Intelligencer both gave significantly different treatment to nuclear power and coal stories $(\mathrm{p}<.001)$. Both papers gave predominantly neutral coverage to coal articles, while nuclear power articles were more frequently polarized. Among the few coal articles that were judged not to be neutral, both papers had more articles favoring than opposing coal. The opposite was true for nuclear power where most articles were polarized and most of these opposed nuclear power.

The number of National Observer articles that favored nuclear power or coal was too small for $\underline{x}^{2}$ analysis, al though it appears that the National Observer opposed both nuclear power and coal, the former more strongly. When all of the newspaper articles are combined, the results parallel those found for the Times and Post-Intelligencer. About two-thirds of the nuclear power stories were handled in a polarized fashion, while only a quarter of the coal stories were polarized.

The magazine findings do not quite parallel the newspaper findings, however (see Table 3). Unfortunately, the frequency of articles for all but Business Week were too small for $\underline{x}^{2}$ testing, so we will focus on the combined magazine results. It can be seen that overall these magazines favored coal by about a 2-to-1 margin and opposed nuclear power by about a 2.5-to-1 margin. 
TABLE 2

Differences in the Likely Effect of Newspaper Articles on a Neutral Reader as a Function of Source

\begin{tabular}{|c|c|c|c|c|c|c|}
\hline \multirow[b]{2}{*}{ Newspaper Source } & & \multicolumn{4}{|c|}{ Likeiy Effect } & \multirow[b]{2}{*}{$\mathrm{p}^{\mathrm{a}}$} \\
\hline & & & Favor & Neutra1 & Oppose & \\
\hline \multirow[b]{2}{*}{ New York Times } & Nuclear & 39 & $(29.8 \%)$ & $44(33.6 \%)$ & $48(36.6 \%)$ & \multirow[b]{2}{*}{.001} \\
\hline & Coat & 13 & $(14.6 \%)$ & $68(76.4 \%)$ & $8(9.0 \%)$ & \\
\hline \multirow[b]{2}{*}{ Seattle Post-Intelligencer } & Nuclear & & $(22.0 \%)$ & $16(39.0 \%)$ & $16(39.0 \%)$ & \multirow[b]{2}{*}{.001} \\
\hline & Coal & 3 & $(15.0 \%)$ & $16(80.0 \%)$ & $1(5.0 \%)$ & \\
\hline \multirow[b]{2}{*}{ National Observer } & Nuciear & 2 & $(5.9 \%)$ & $14(41.2 \%)$ & $18(52.9 \%)$ & \multirow[b]{2}{*}{ b } \\
\hline & Coal & 2 & $(13.3 \%)$ & $8(53.3 \%)$ & $5(33.3 \%)$ & \\
\hline \multirow{2}{*}{ TOTAL } & Nuclear & 50 & $(24.3 \%)$ & $74(35.9 \%)$ & $82(39.8 \%)$ & \multirow[b]{2}{*}{.001} \\
\hline & $\cos 1$ & 18 & $(14.5 \%)$ & $92(74.2 \%)$ & $14(11.3 \%)$ & \\
\hline
\end{tabular}

${ }^{\text {a }}$ See Table 1 for a discussion of the meaning of probability (p).

Number of cases too small for $\underline{x}^{2}$ test. 
TABLE 3

Differences in the Likely Effect of Magazine Articles on a Neutral Reader as a Function of Source

\begin{tabular}{|c|c|c|c|c|c|}
\hline \multirow[b]{2}{*}{ Magazine Source } & & \multicolumn{3}{|c|}{ Likely Effect } & \multirow[b]{2}{*}{$\mathrm{p}^{2}$} \\
\hline & & Favor & Neutral & Oppose & \\
\hline \multirow[b]{2}{*}{ Time } & Nuclear & $2(14.3 \%)$ & $7(50.0 \%)$ & $5(35.7 \%)$ & \multirow[b]{2}{*}{ b } \\
\hline & Coal & $3(21.4 \%)$ & $8(57.1 \%)$ & $3(21.4 \%)$ & \\
\hline \multirow[b]{2}{*}{ Business Week } & Nuclear & $10(22.7 \%)$ & $20(45.5 \%)$ & $14(31.8 \%)$ & \multirow[b]{2}{*}{.05} \\
\hline & Coa 1 & $10(26.3 \%)$ & $24(63.2 \%)$ & $4(10.5 \%)$ & \\
\hline \multirow{2}{*}{ Scientific American } & Nuclear & $8(44.4 \%)$ & $7(38.9 \%)$ & $3(16.7 \%)$ & \multirow[b]{2}{*}{ b } \\
\hline & Coar & $6(75.0 \%)$ & $0(0.0 \%)$ & $2(25.0 \%)$ & \\
\hline \multirow[b]{2}{*}{ Environment } & Nuclear & $3(6.3 \%)$ & $8(16.7 \%)$ & $37(77.1 \%)$ & \multirow[b]{2}{*}{$b$} \\
\hline & Coa 1 & $4(57.1 \%)$ & $0(0.0 \%)$ & $3(42.9 \%)$ & \\
\hline \multirow{2}{*}{ TOTAL } & Nuclear & $23(18.5 \%)$ & $42(33.9 \%)$ & $59(47.6 \%)$ & \multirow{2}{*}{.001} \\
\hline & Coal & $23(34.3 \%)$ & $32(47.8 \%)$ & $12(17.9 \%)$ & \\
\hline
\end{tabular}

${ }^{a}$ See Table 1 for discussion of the meaning of probability $(p)$.

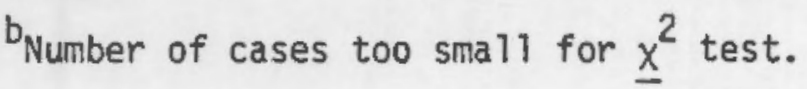


As with the newspapers, nuclear power stories were more frequently polarized but not by a very large margin. Business Week favored coal over nuclear $(\mathrm{p}<.05)$, as did Environment, al though surprisingly coal was infrequently covered by Environment. Time appeared to give coal balanced treatment while opposing nuclear power. Scientific American favored both energy technologies with coal getting the more favorable treatment. Scientific American was unique among our sources in being the only one to have more articles favoring than opposing nuclear power.

The analysis over time of the number of articles opposing or favoring each technology is shown in Figure 2. Newspaper and magazine results are combined. Whereas the number of antinuclear articles steadily increased from 1972 through 1976, the number of anticoal articles remained virtually the same from 1972 through 1976. Pronuclear articles increased somewhat over this time period, whereas the number of procoal articles peaked in 1973. Finally, the number of both the neutral nuclear and neutral coal articles peaked in 1974 and dropped off in 1975. However, the number of neutral nuclear articles exceeded the 1974 peak in 1976, whereas the number of neutral coal articles continued the downward trend started in 1975 following the 1974 high point.

The results of the analysis of differences in the cost/benefit measure for coal and nuclear were not as clear-cut. Regarding the three newspapers (see Table 4), only the New York Times had enough articles for $\underline{x}^{2}$ testing. The Times did handle nuclear power and coal differently $(\mathrm{p}<.001)$. The main reasons for the significant difference were that (in order of importance) more coal but fewer nuclear articles than expected discussed "mostly costs, but some benefits," fewer coal but more nuclear articles than expected discussed "benefits only," and fewer coal but more nuclear articles than expected discussed "costs only." For all of the newspaper articles combined, there was 
FIGURE 2

The Number of Pro, Neutral, and Anti Nuclear Power and Coal Articles by Year

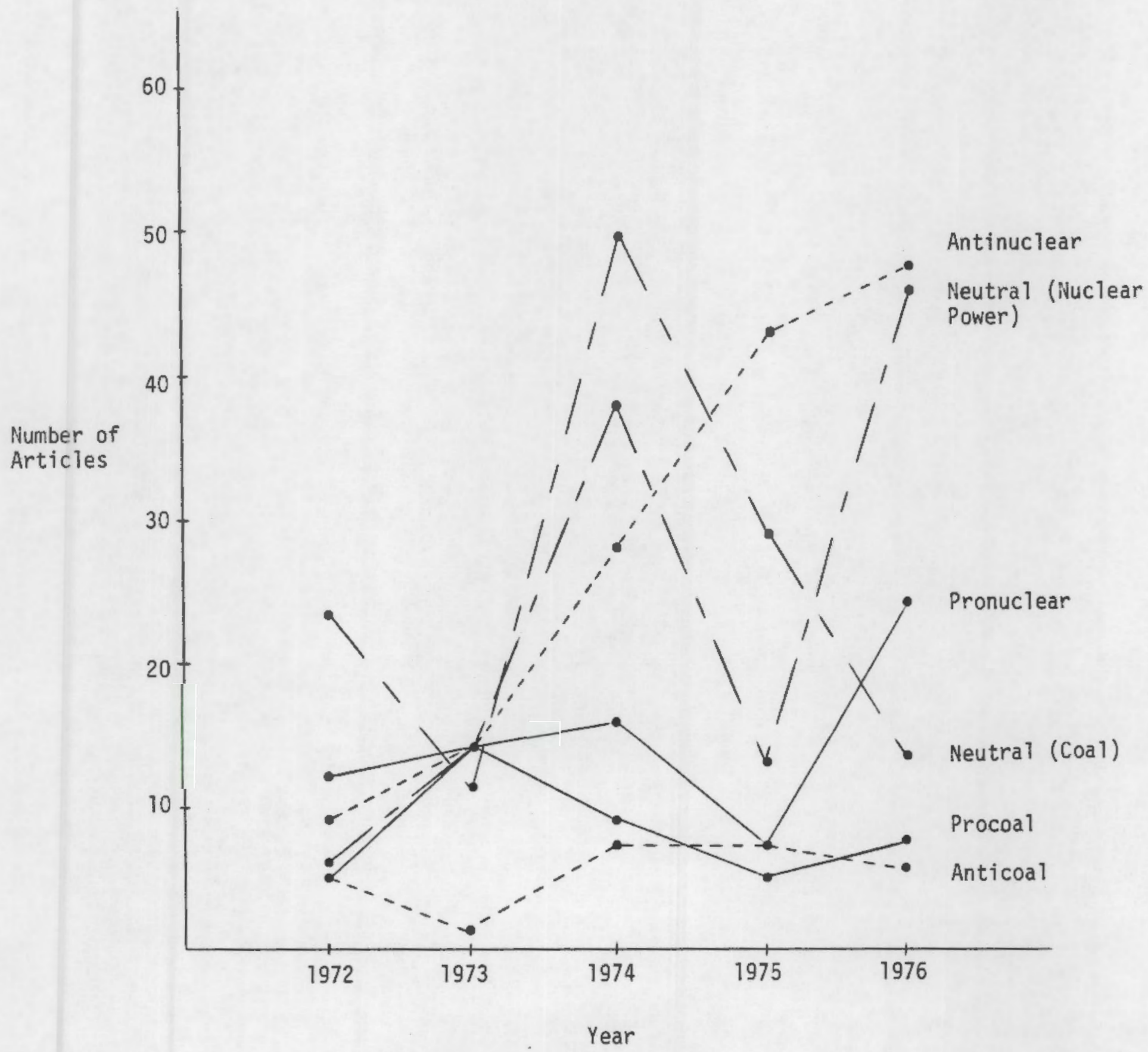


TABLE 4

Differences in the Discussion of Benefits and Costs

of Huclear Power and Coal as a Function of Mewspaper Source

\begin{tabular}{|c|c|c|c|c|c|c|c|c|}
\hline \multirow[b]{2}{*}{ Mewspaper Source } & & \multirow[b]{2}{*}{$\begin{array}{l}\text { Benefits } \\
\text { Only }\end{array}$} & \multirow[b]{2}{*}{$\begin{array}{l}\text { Mostly Benefits, } \\
\text { Som Costs }\end{array}$} & \multicolumn{2}{|c|}{ Benefit/Cost Discussion } & \multicolumn{2}{|l|}{ ' } & \multirow[b]{2}{*}{$\mathrm{p}^{\mathrm{a}}$} \\
\hline & & & & $\begin{array}{l}\text { Benefits and } \\
\text { Costs Equally }\end{array}$ & $\begin{array}{l}\text { Mostly Costs, } \\
\text { Some Benefits }\end{array}$ & $\begin{array}{l}\text { Costs } \\
\text { Only }\end{array}$ & $\begin{array}{l}\text { Mot } \\
\text { Discussed }\end{array}$ & \\
\hline & Nuclear Power & $17(13.0 \%)$ & $7(5.38)$ & $15(11.5 \%)$ & $7(5.34)$ & $45(34.4 x)$ & $40(30.5 \%)$ & \\
\hline New York Times & Coal & $4(4.5 \%)$ & $8(9.0 x)$ & $4(4.5 \%)$ & $17(19.18)$ & $18(20.2 \%)$ & $38(42.7 \%)$ & .001 \\
\hline \multirow[b]{2}{*}{ Seattle Post Intelligencer } & Nuclear Power & $3(7.3 x)$ & $0(0.0 x)$ & $5(12.2 x)$ & $4(9.8 x)$ & $12(29.3 \%)$ & $17(41.5 x)$ & \multirow[b]{2}{*}{ b } \\
\hline & Coal & $1(5.0 x)$ & $1(5.0 x)$ & $1(5.0 \%)$ & $1(5.0 x)$ & $2(10.0 \%)$ & $14(70.0 \%)$ & \\
\hline \multirow[b]{2}{*}{ National Observer } & Nuclear Power & $1(2.9 \%)$ & $1(2.9 x)$ & $7(20.6 \%)$ & $5(14.7 x)$ & $14(41.28)$ & $6(17.6 x)$ & \multirow[b]{2}{*}{ b } \\
\hline & Coal & $0(0.0 \%)$ & $1(6.7 x)$ & $4(26.7 \%)$ & $4(26.7 \%)$ & $3(20.0 \%)$ & $3(20.02)$ & \\
\hline \multirow[b]{2}{*}{ TOTAL. } & Nuclear Power & $21(10.28)$ & $8(3.95)$ & $27(13.1 x)$ & $16(7.8 x)$ & $71(34.5 \%)$ & $63(30.6 \%)$ & \multirow[b]{2}{*}{.001} \\
\hline & Coal & $5(4.0 x)$ & $10(8.18)$ & $9(7.38)$ & $22(17.7 x)$ & $23(18.52)$ & $55(44.4 \%)$ & \\
\hline
\end{tabular}

${ }^{a}$ See Table 1 for a discussion of the meaning of probability (p).

bumber of cases too small for a $\chi^{2}$ test. 
also a significant difference in the handling of nuclear power and coal articles $(p<.001)$. The main reasons for this significant difference in news handling were that (in order of importance) fewer coal but more nuclear articles than expected discussed "costs only," more coal but fewer nuclear articles than expected discussed "mostly costs, but some benefits," and more coal but fewer nuciear articles than expected did "not discuss" costs and benefits of the technology. These data support the conclusion mentioned earlier that nuclear power is handled in a more polarized manner than coal.

The differences in discussion of benefits and costs of nuclear power and coal as a function of magazine source were also examined (see Table 5). None of the specific sources had enough nuclear and coal articles for significance testing on a specific source basis. In the aggregate, however, the magazine coverage of nuclear power and coal could be compared. This comparison found no differences in the benefit/cost discussion of nuclear power and coal. Thus, in terms of this aggregate measure, magazines did not differ on nuclear power and coal articles.

In summary, the print media have handled nuclear power stories in a more polarized manner than has been the case with coal stories. Coal stories were most frequently handled by the newspapers in a neutral manner. Magazine articles tended to be more procoal than pronuclear. A major difference between nuclear power and coal articles has been media handling over time. Whereas antinuclear articles increased at a much higher rate than pronuclear articles from 1972 through 1976, the number of both procoal and anticoal articles stayed somewhat the same over this time period. Thus, the print media tended to become increasingly antinuclear from 1972 through 1976 . Overa11, a large majority of coal articles were neutral, but the number of neutral articles has been reducing since 1974 . 
TABLE 5

Differences in the Discussion of Benefits and Costs

of Muclear Power and Coal as a Function of Magazine Source

\begin{tabular}{|c|c|c|c|c|c|c|c|c|}
\hline \multirow[b]{2}{*}{ Magazine Source } & & \multicolumn{6}{|c|}{ Benefit/Cost Discusssion } & \multirow[b]{2}{*}{$\mathrm{R}^{\mathrm{a}}$} \\
\hline & & $\begin{array}{l}\text { Benefits } \\
\text { Only }\end{array}$ & $\begin{array}{l}\text { Mostly Benefits, } \\
\text { Some Costs }\end{array}$ & $\begin{array}{l}\text { Benefits and } \\
\text { Costs Equally }\end{array}$ & $\begin{array}{l}\text { Mostiy Costs, } \\
\text { Some Benefits }\end{array}$ & $\begin{array}{l}\text { Costs } \\
\text { Only }\end{array}$ & $\begin{array}{c}\text { Mot } \\
\text { Discussed }\end{array}$ & \\
\hline \multirow[b]{2}{*}{ Time } & Nuclear Power & $0(0.0 x)$ & $0(0.0 \%)$ & $7(50.08)$ & $4(28.6 x)$ & $2(14.32)$ & $1(7.1 \%)$ & \\
\hline & Coal & $1(7.1 x)$ & $1(7.1 \%)$ & $3(21.4 x)$ & $2(14.3 \%)$ & $6(42.95)$ & $1(7.1 x)$ & b \\
\hline \multirow[b]{2}{*}{ Bus iness Heek } & Nuclear Power & $1(2.38)$ & $7(15.94)$ & $9(20.5 z)$ & $10(22.7 x)$ & $7(15.96)$ & $10(22.78)$ & \\
\hline & Coal & $0(0.0 \%)$ & $6(15.82)$ & $6(15.8 \%)$ & $5(13.2 x)$ & $8(21.14)$ & $13(34.2 x)$ & b \\
\hline \multirow[b]{2}{*}{ Scientific American } & Nuclear Power & $4(22.28)$ & $3(16.7 x)$ & $4(22.28)$ & $2(11.1 \%)$ & $3(16.7 x)$ & $2(11.12)$ & \\
\hline & Coal & $1(12.5 \%)$ & $4(50.0 \%)$ & $1(12.5 x)$ & $1(12.5 \%)$ & $1(12.5 \%)$ & $0(0.0 \%)$ & b \\
\hline \multirow[b]{2}{*}{ Environsent } & Nuclear Power & $1(2.1 x)$ & $0(0.0 z)$ & $6(12.5 \%)$ & $8(16.7 \%)$ & $29(60.48)$ & $4(8.38)$ & \\
\hline & Coal & $1(14.38)$ & $1(14.38)$ & $1(14.37)$ & $2(28.6 \%)$ & $2(28.62)$ & $0(0.0 \%)$ & b \\
\hline \multirow{2}{*}{ TOTAL } & Nuclear Power & $6(4.8 x)$ & $10(8.18)$ & $26(30.0 \%)$ & $24(19.43)$ & $41(33.12)$ & $17(13.7 x)$ & \\
\hline & $\operatorname{con} 1$ & $3(4.5 \%)$ & $12(17,9 q)$ & $11(16.4 \%)$ & $10(14.9 \%)$ & $17(25.4 \%)$ & $14(20.9 \%)$ & n.s. \\
\hline
\end{tabular}

${ }^{a}$ See Table 1 for a discussion of the meaning of probability ( $p$ ).

Humber of cases too small for a $\underline{x}^{2}$ test. 


\section{SUMMARY AND DISCUSSION}

In summary, nuclear power has been a more important topic than has coal for the print media, and has received somewhat different treatment. Compared to the number of coal articles, almost twice as many nuclear power articles were printed from 1972 through 1976. Also, while the number of nuclear power articles increased somewhat steadily from 1972 through 1976, the number of coal articles peaked in 1974 and has decreased since. The newspapers that we sampled gave more prominence to nuclear articles in terms of article type and article location. Also, nuclear articles were more often issue-oriented compared to coal articles.

The areas and issues covered in the articles also differed. Coal articles were most often about coal mining, labor force concerns, and regulations and controls. Nuclear power articles, on the other hand, were mostly about reactor operation. The main issues discussed in the coal articles pertained most to political decisions affecting coal use, to strikes, and to health and safety. The main nuclear issues pertained to economics, to health and safety, and to political decisions.

Newspapers handled nuclear power articles in a more polarized manner compared to coal articles which were handled in a more neutral manner. Magazine articles were significantly more antinuclear than anticoal. A7so, the print media became more antinuclear from 1972 throuch 1976, whereas the print media did not become more anticoal. The Tikely effect of these differences is to place coal in a more favorable perspective than nuclear power. These data, of course, cannot be used to determine whether the media created the nuclear power controversy or whether they only reported the controversy. Regardless, print media handling is likely to have kept the controversy alive. 
Readers should be cautioned that our findings regarding "likely effect on a neutral reader" must not be interpreted as "actual effect on the American public." Obviously, a great many factors contribute to energy attitudes (see, for instance, Melber, Nealey, Hanmersla, and Rankin, 1977; Nealey and Rankin, 1978; and Rankin and Nealey, 1979 for discussion of energy attitude determinants). Documenting a causal connection between media treatment of a given topic and public attitudes is far beyond the scope (and budget) of the present study.

We should also note that the present findings do not constitute evidence of "bias" on the part of the print media. The media are under no obligation to devote equal space to the "good news" and "bad news" on any topic (see Nealey, 1979 for a fuller discussion).

Finally, we did not attempt to assess the accuracy of coverage of either nuclear power or coal topics. Inspection of print media material on these topics shows that only a tiny fraction of the article content lends itself to verification as fact or truth. While the impression we get from discussing this question with energy technologists is that media coverage is very frequently in error, we are inclined to guess that this overstates the situation. Scanlon, Luukko, and Morton (1978) have analyzed the accuracy of media reporting on disasters and concluded that specific errors do occur with some frequency but rarely alter the overall impression left by the article.

A point worth noting in this connection is media treatment of risk. Since some risk is invariably associated with the development of any energy technology, it is quite legitimate to discuss possible risks as a part of media articles. Since both the magnitude of the consequences and the probability of occurrence of harmful events are subject to varying estimates, it is not surprising that media characterization of risk sometimes appears inaccurate. 


\section{REFERENCES}

Melber, B. D., Nealey, S. M., Hammersla, J., and Rankin, W. L. 1977. Nuclear Power and the Public: Analysis of Collected Survey Research (PNL-2430). Battelle Human Affairs Research Centers, Seattle, Washington.

Nealey, S. M. 1979. Perspective on public acceptance of nuclear power. American Industrial Hygiene Association Journal, in press.

Nealey, S. M., and Rankin, W. L. 1978. Nuclear Knowledge and Nuclear Attitudes: Is Ignorance Bliss? (B-HARC-411-002). Battelle Human Affairs Research Centers, Seattle, Washington.

Rankin, W. L., and Nealey, S. M. 1979. The Relationship of Human Values and Energy Beliefs to Nuclear Power (B-HARC-4TT-007). Battelle Human Affairs Research Centers, Seattle, Washington.

Rankin, W. L., Nealey, S. M., and Montano, D. 1978. Analys is of Print Media Coverage of Nuclear Power Issues (PNL-2660, B-HARC-411-001), Battelle Human Affairs Research Centers, Seattle, Washington.

Scanlon, T. J., Luukko, R., and Morton, G. Media coverage of crisis: Better than reported, worse than necessary. Journalism Quarterly, 1978, 55 (1), 68-72. 
No. of

Copies

W. Ballard, Jr.

DOE Office of Energy Programs

Washington, O.C. 20545

D. L. Bodde

Office of Nuclear Policy, Energy Research

Washington, D.C. 20585

\section{A. A. Churm}

DOE Chicago Patent Group

9880 South Cass Avenue

Argonne, IL 60439

J. Cohen

Lawrence Livermore Laboratory

Livermore, CA 94550

T. Cotton

Office of Technology Assessment

Washington, D.C. 20510

27 DOE Technical Infomation Center

P.0. Box 62

Oak Ridge, TN 37830

C. H. George

DOE Office of Nuclear Waste

Management

Washington, D.C. 20545

T. Greenwood

Office of Science and Technology Policy

Washington, D.C. 20500

G. Graves

Los Alamos Scientific Laboratory Los Alamos, NM 87544

C. A. Heath

DOE Office of Nuclear Waste

Management

Washington, D.C. 20545

T. C. Hobson

DOE Office of Consumer Affairs Washington, D.C. 20545
No. of

Copies

C. Jolly

OOE Office of the Environment

Washington, O.C. 20545

N. LOW

HEW Office of the Secretary

Washington, D.C. 20201

J. B. Martin

NRC Division of Fuel Cycle and Material Safety

Washington, D.C. 20555

B. E. McCarty

DOE Office of Public Affairs

Washington, D.C. 20545

Or. William A. Mills

Acting Deputy Administrator

for Radiation Programs

ANR 458

USEPA

401 M Street SW

Washington, D.C. 20460

G. Dertel

DOE Office of Nuclear Waste Management

Washington, D.C. 20545

A. F. Perge

DOE Office of Nuclear Waste Management

Washington, D.C. 20545

J. Pomeroy

National Academy of Sciences

Washington, D.C. 20418

J. Sullivan

DOE Office of Public Affairs

Washington, D.C. 20545

S. L. Topp

Savannah River Laboratory

Aiken, SC 29801 
No. of

Copies

Richland Operations Office

3 Contract Office

R. B. Goranson

Office of Nuclear Waste Isolation

N. Carter

D. Keller

Battelle Northwest

Technical Files

Publishing Coordination

T. W. Ambrose

J. B. Burnham

D. E. Deonigi

J. J. Fuquay

M. R. Kreiter

A. M. Platt

J. V. Robinson

25 M. W. Shupe 